\title{
Substantiation of resource-saving technology when mining the deposits for the production of crushed-stone products
}

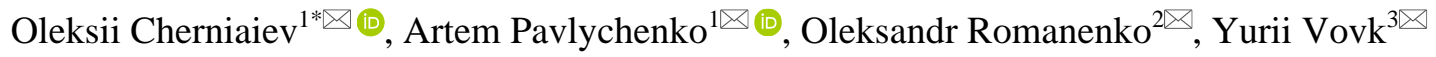 \\ ${ }^{1}$ Dnipro University of Technology, Dnipro, 49005, Ukraine \\ ${ }^{2}$ Ukrainian Academy of Mining Sciences, Kryvyi Rih, 50002, Ukraine \\ ${ }^{3}$ National University of Water and Environmental Engineering, Rivne, 33028, Ukraine \\ *Corresponding author: e-mail chernyaev.aleksey82@gmail.com, tel. +380952574060
}

\begin{abstract}
Purpose. Scientific substantiation of the expedient depth of mining the non-metallic deposits of rocky minerals on the basis of mathematical and statistical methods, which will ensure resource-saving and rational use of natural resources.

Methods. To solve the purpose set, the following methods are used: graphical-analytical - when optimizing the maximum depth of mining the deposits of building materials, and the method of mathematical modeling - for determining the maximum depth of mining the non-metallic deposits with internal dumping. By means of statistical processing according to systematized types of deposits, the patterns of a change in the maximum depth of mining the basic deposits, depending on the main parameters of the quarry field, have been studied.

Findings. A new methodology, which is distinguished by taking into account in-pit dumping, has been developed for calculating the maximum depth of granite quarries, which most of all influences the efficiency of mining operations and the value of economic indicators while ensuring the maximum economic effect with the achievement of a rational maximum depth of mining the deposit. A new, theoretically substantiated methodology has been created for determining the maximum depth of mining the mineral deposits for the production of crushed-stone products while providing the resource- and land-saving during the quarry operation.

Originality. For the first time for these deposits, the dependence of their maximum mining depth on the main parameters of the quarry field and the place of internal dumping of overburden rocks has been determined. This has become a determining factor in the appropriate mining of deep non-metallic deposits of building materials with internal dumping, which provides a minimal land disturbance.

Practical implications. The research results have been tested and implemented in working projects for mining the Liubymivske, Chaplynske, Pervomaiske, Mykytivske, Trykratske and Novoukrainske granite deposits; as a result of additional mining of mineral reserves, their additional increment in the volume from 1 to 48 million $\mathrm{m}^{3}$ is possible, which will ensure 5-40 years of sustainable operation of the mining enterprise.
\end{abstract}

Keywords: non-metallic quarries, quarry mining plan, depth of dumping, in-pit dumping, maximum mining depth

\section{Introduction}

Ukraine is one of the leading places in the world in terms of reserves of rocky non-metallic raw materials suitable for the production of building materials. Deposits of rocky building materials in Ukraine belong to the deposits of igneous rocks of the Ukrainian Crystalline Massif and are widespread deep into the earth's crust, forming laccoliths, batholiths, bunches and other deposits [1]-[2]. Most fields of sedimentary building materials are mined to a depth of 80-120 m to the deposit bottom using the technology with internal dumping. Deposits of pyrogenetic rocks are mined to a depth of 70-100 m, sometimes 140-150 m with external dumping [3].
In the practice of designing the indicated deposits of pyrogenetic and metamorphic rocks, their maximum mining depth is limited by many parameters: the depth of the explored mineral reserves; increased groundwater inflow at a great depth, which leads to a sharp increase in the cost of water-removing and drainage; built-up area adjacent to the quarry fields, which limits their spatial dimensions; possible increase in radioactivity of minerals with depth; small transverse dimensions of igneous rock deposits [4]-[6].

A significant number of more than 300 quarries of igneous rocks in Ukraine have now reached their design depth. There is no possibility to expand the quarry field boundaries 
by increasing the reserves in the flanks. This is conditioned by the necessity of relocating the roads, buildings, structures, pipelines, power lines, as well as the allocation of new areas of privatized land. It remains to implement another way - to develop mining operations in depth, increasing the reserves located below. At the same time, the scientific substantiation of the rational maximum depth of mining such deposits, especially during their mining with internal dumping of overburden rocks, has not been performed. In this regard, an important task arises to determine the maximum depth of mining the deposits of non-metallic building materials.

The first printed works on the determination of the quarry boundaries date back to 1924 . Since 1927, the problems of determining the depth of quarries have been intensively studied. In those years, such studies were based on the quarries of Kryvyi Rih, which already had a depth of 80-100 m. At this stage, when conducting mining operations in a surface way, a method based on the comparison of the contour and the average expedient stripping ratio was used to determine the final depth of the quarry.

Problems of the theory development of surface mining the mineral deposits are presented in the works of Ukrainian [7][12] and foreign scientists [13]-[15]. Analysis of these works, design solutions and research, carried out at mining enterprises extracting minerals, has shown that the efficiency of mining operations is primarily determined by the issues of resource-based [16], [17] ecological expediency [18], [19], as well as developed transport achievements [20]-[22].

In general, the analysis of the technology of dump operations indicates that about $85 \%$ of all quarries for the extraction of sedimentary rocks and $100 \%$ of pyrogenetic rocks are mined using the technology with the overburden rocks transfer to external dumps [23], [24]. This is characterized by the use of traditional technology of the fields development in the process of their design. To a greater extent, the research results are devoted to the problems of improving the technology of surface mining of the deposits for the extraction of rocky non-metallic minerals [25]-[27]. However, the task of scientific substantiation of the maximum depth of mining the above-mentioned mineral deposits for the production of crushed-stone products remains unsolved.

Mineral raw materials should be extracted with account of the technologies that meet the following requirements [28]-[31]:

- minimal disturbance of the structure and fertility of lands;

- use of the most environmentally friendly equipment during surface mining;

- the use of modern environmentally friendly methods of dust prevention and dust suppression during production processes;

- the use of special methods and techniques for performing blasting operations that will minimize the emission of dust/gas substances (or completely exclude them), seismic impact on the adjacent objects from a charge unit, shock wave and scattering of rock pieces in different directions;

- the most complete use of the created mined-out areas of the quarries;

- completeness of minerals extraction;

- ensure dewatering of fields and drainage works during the extraction of raw materials in such ways that best provide the natural or close to it hydrological regime of the region without significant changes in the direction of supplying the enterprises and the population with volumes of drinking and industrial water;
- reclamation and revitalization of lands disturbed by mining operations to the most ecologically acceptable landscapes of territories and their recreation.

At the same time, mineral deposits should be mined taking into account the development of Clean High Technologies during mining the deposits of different types of origin, as well as the technology of their mining [32]-[36].

Quarries for the extraction of rocky non-metallic minerals for the production of crushed-stone products operate in many regions of the country. Most of these fields are mined to a depth of 40-130 $\mathrm{m}$ and, in rare cases, $150 \mathrm{~m}$. Quarries of a small area (up to $20 \mathrm{ha}$ ) are mined to a depth of 43-93 m (on average $60 \mathrm{~m}$ ), a medium area (20-60 ha) - to a depth of $50-100 \mathrm{~m}$ (on average $77 \mathrm{~m}$ ), a large area (more than $60 \mathrm{ha}$ ) to a depth of 58-130 $\mathrm{m}$ (on average $87 \mathrm{~m}$ ) [1], [37], [38].

Deposits of igneous and metamorphic rocks are distinguished by significant diversity in composition, thickness, structure of deposits, location relative to the levels of predominant surface, shape and sizes, approved reserves, water cut and water content, thickness and nature of overburden rocks [39], [40].

The depth of mining the mineral deposits has a great influence on the quality and physical-and-mechanical properties of mineral resources [41]. With increasing the depth, the rocks are less exposed to weathering, as a result of which the strength of minerals increases [42]. There is also a decrease in fracturing, which can influence on a change in the system or scheme of the field development, but it can still occur due to natural factors [43], [44].

The depth of mining such deposits is influenced by many factors that constraint the depth of mining the quarries of building materials [29], [30], [38]:

- spatial dimensions of deposits (length, width);

- depth of explored mineral reserves;

- increased inflow of groundwater (with increasing depth) and surface water (with increasing spatial dimensions of the quarry field);

- change in indicators of radioactivity and other harmful radiation of minerals with increase in mining depth;

- built-up area adjacent to the quarry fields, which limits their spatial dimensions;

- change in the hydrogeological regime in adjacent settlements and on agricultural lands located near the fields;

- volumes of overburden rocks that are stockpiled in the mined-out space;

- economic indicators of rational extraction of raw materials (mining cost of $1 \mathrm{~m}^{3}$ and the level of profitability).

Based on the analysis of the current state and the existing practice of mining enterprises operation, scientific-technical literature and scientific research on determining the maximum rational depth of mining the granite and stone quarries, it can be concluded that the further design of granite quarries to their rational maximum depth is relevant, primarily without expanding of their flanks. The above provisions determine the relevance of the research on substantiation of the maximum depth of mining the non-metallic deposits with internal dumping, without additional expanding of their flanks beyond the boundaries of the existing mining allotment, which leads to a decrease in the area of additional land for mining operations.

The purpose of the research is to substantiate the expedient depth of mining the non-metallic deposits of rocky minerals, which will ensure the rational use of natural 
resources. To achieve this purpose, it is necessary to solve the following tasks:

- to set the optimal depth of internal dumping, which ensures the maximum depth of mining the deposit;

- determine the growth of the total cost of finished products with the depth of mining operations;

- substantiate the economically expedient depth of mining the typical deposits;

- substantiate the depth of mining the non-metallic deposits of rocky minerals with stockpiling the overburden rocks in the mined-out space.

\section{Research methods}

When optimizing the depth of mining the non-metallic deposits with in-pit stockpiling of overburden rocks, the determining parameters are the length and width of the deposit. These parameters are taken into account for determining the final depth of the quarry field [45], [46]. One of the most important factors influencing the implementation of the resourcesaving technology for mining the above-mentioned deposits during in-pit stockpiling of overburden rocks is their thickness. Analyzing the above, a general systematization of non-metallic deposits of rocky minerals for the production of crushed-stone products has been developed, where the allocation of basic deposits, as objects of further research, is performed according to the spatial dimensions and thickness of overburden rocks.

Given the accepted classification criteria, 9 basic (typical) deposits are identified, the averaged parameters of which are presented in the work [30]. These types of deposits are proposed as the main objects for further research on resourcesaving technologies and the development of a methodology for determining the maximum economically expedient depth of their mining with in-pit stockpiling of overburden rocks. The use of the proposed basic deposits of granite and stone raw materials will provide the research with a high convergence of the theoretical and practical results, which is important when implementing the ecological, land- and resource-saving technologies for mining the deposits of igneous rocks for the production of crushed-stone products and building materials.

Based on the tasks set for the research on rational schemes for mining the non-metallic quarries of building materials, possible schemes will be considered and the most rational one for conducting mining operations will be selected, ensuring the feasibility and efficiency of the field development. Let us study the following technological schemes for mining the deposits [29], [47], [48] (Fig. 1).

Scheme A - with this scheme, the deposit is mined to a depth of the design level, until all the explored commercial reserves of the field are extracted. At the same time, at the moment of reaching the design level of one of the quarry ends (stage I), the formation of an internal dump begins, which is located at the bottom of the quarry. This scheme can be used in quarries with a depth of estimated reserves up to $70 \mathrm{~m}$, for the quarries with a large area up to 100-120 m.

Scheme B - this scheme is similar to scheme A. The difference is that the internal dump is located at the level above the design level. This scheme is used when it is impossible to form a dump at the design level of the bottom due to any factors. It can be used in quarries with a depth of estimated reserves of 100-120 m. In this case, internal dumping occurs at a depth of 60-70 m (stage I) with its subsequent transfer to the design depth after the stage II development. (a)

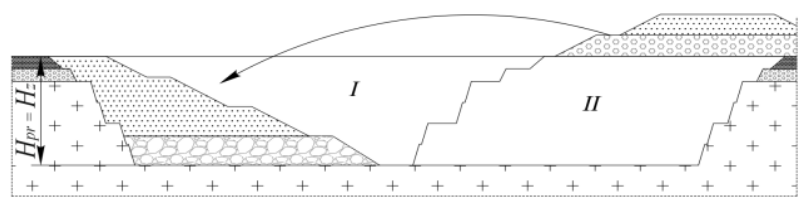

(b)

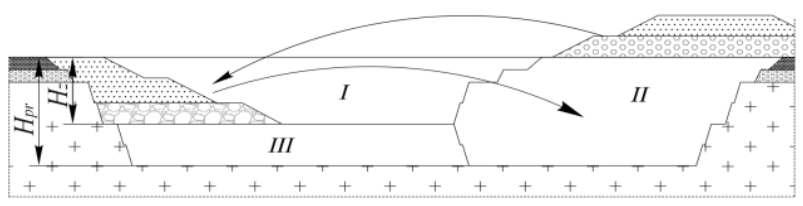

(c)

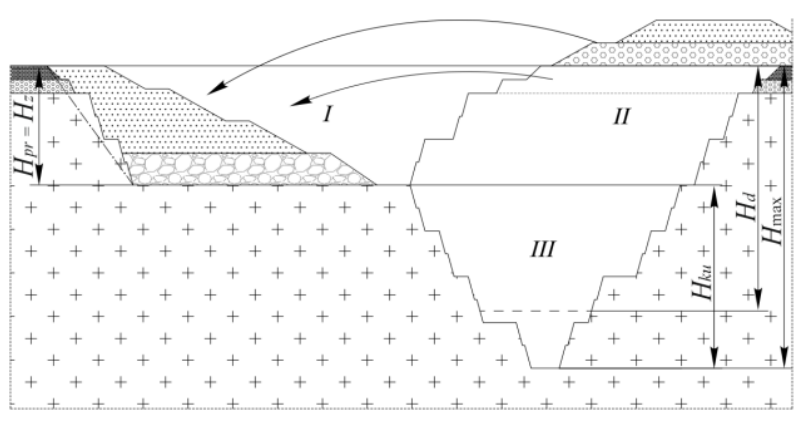

(d)

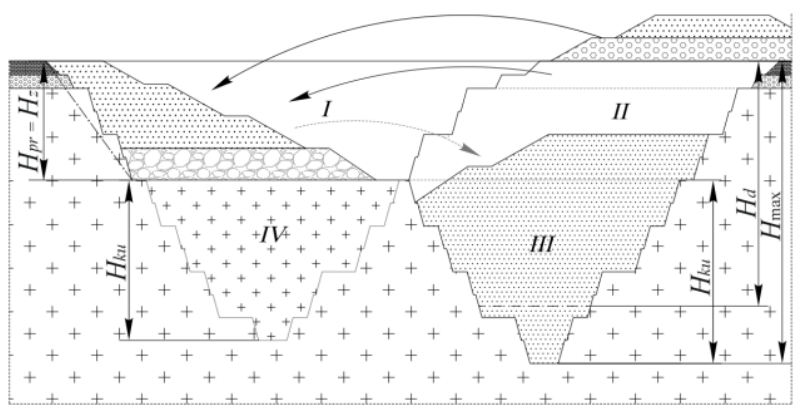

Figure 1. Schemes for mining the non-metallic quarries of building materials with dumping of overburden rocks: (a) at the design depth without deepening the quarry, "scheme A"; (b) above the design depth without deepening the quarry, "scheme B"; (c) at the design depth with the additional mining of the field in depth, "scheme C"; (d) below the design depth with the additional mining of the field in depth, "scheme D"; $H_{d e s}-$ design depth of the quarry; $H_{\text {fill }}$ - the depth of filling the dump; $H_{\text {exp }}-$ expedient depth of mining the quarry; $\mathrm{H}_{q(\max )}$ - maximum depth of mining the quarry with deepening of mining operations; I, II, III, IV-stages of mining the quarry

Scheme $\mathrm{C}$ - this scheme provides for the mining of the deposit to the maximum possible depth, without push back of the flanks, and provides for internal dumping at the design level. After the completion of operations at the stage II, a significant area of the quarry bottom remains, where it is possible to conduct additional mining of reserves with their putting on the balance sheet, and then mine out these reserves.

Scheme D is similar to scheme C, but at the moment of reaching the maximum depth (stage III) the internal dump is re-laid on the lower horizons, after which the quarry is further additionally mined out at the end, where the internal dump was previously located. 
The maximum depth of mining the granite quarries $\left(H_{\max }\right)$ is determined taking into account the formation of an internal dump of overburden rocks, as well as its location (Fig. 2a, b).

(a)

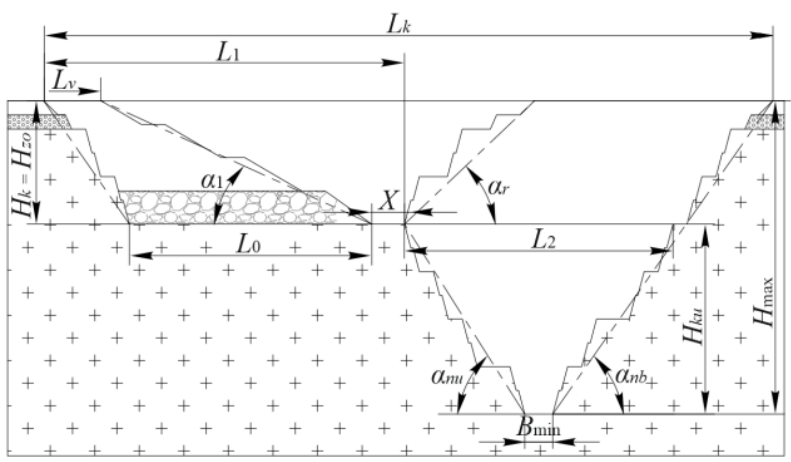

(b)

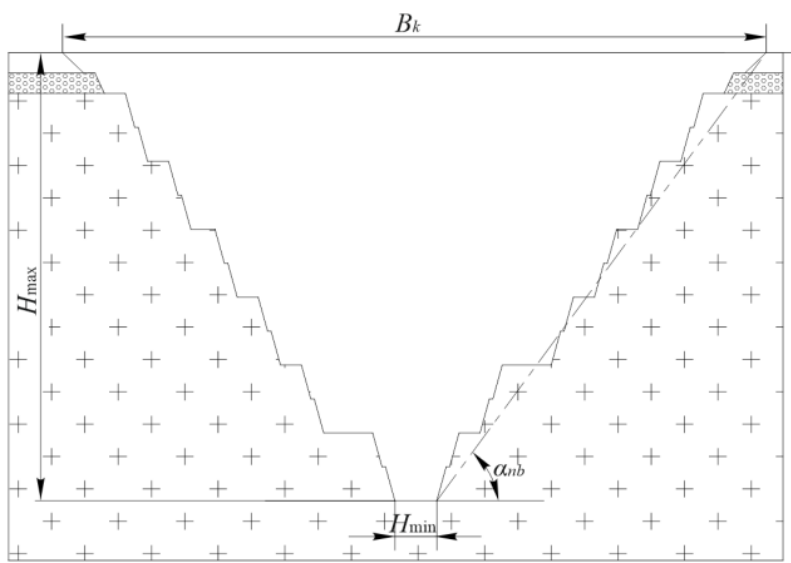

Figure 2. Scheme for determining the parameters of mining the quarry to the maximum depth: (a) by its length; (b) by its width

$H_{\max }=\frac{H_{f i l l}+\left[L_{q}-\left(\frac{V_{d}}{B_{d} \cdot H_{d}}+\frac{H_{d}}{2} \times\right.\right.}{2 \operatorname{ctg} \alpha_{r}}$

$\frac{\left.\left.\times\left(\operatorname{ctg} \alpha_{D . r}-\operatorname{ctg} \alpha_{N}\right)+X+2 H_{f i l l} \cdot \operatorname{ctg} \alpha_{N}\right)\right]-B_{\min }}{2 \operatorname{ctg} \alpha_{r}}, \mathrm{~m}$,

where:

$H_{\text {fill }}$ - depth of dumping, m;

$L_{q}$ - quarry field length, m;

$V_{d}$-internal dump volume, $\mathrm{m}^{3}$;

$B_{d}$ - internal dump width, m;

$H_{d}$ - internal dump height, $\mathrm{m}$;

$\operatorname{ctg} \alpha_{D . r}$ - resulting slope angle of a dump, deg;

$\alpha_{N}$ - non-mining slope angle of a flank, deg;

$X$ - safety platform from the dump to the upper edge of the deepened area, $\mathrm{m}$;

$B_{\text {min }}$ - minimum width of the quarry bottom, m;

$A_{r}$ - resulting slope angle of a flank, deg;

The maximum depth of the quarry for scheme D [29],

[47], [48] can be determined, if $L_{o} \geq L_{2}$, by the formula:

$H_{\max }=H_{\text {fill }}+\frac{\left(\frac{V_{d}}{B_{d} \cdot H_{d}}+\frac{H_{d}}{2}\left(\operatorname{ctg} \alpha_{D . r}-\operatorname{ctg} \alpha_{N}\right)\right)-B_{\min }}{2 \operatorname{ctg} \alpha_{r}}, \mathrm{~m}$
The maximum depth of mining across the width of the quarry field will be:

$$
H_{\max }=\frac{B_{q}-B_{\min }}{2 \operatorname{ctg} \alpha_{r}}, \mathrm{~m} .
$$

\section{Results and discussion}

As a result of the performed calculations, the dependences of the maximum depth of mining $\left(H^{q} \max \right)$ on the depth of internal dumping $\left(H_{\text {fill }}\right)$ have been determined. Analyzing the results obtained, it can be concluded that the depth of internal dumping to the greatest extent influences on the maximum depth of mining the quarries with low and medium thickness of overburden rocks. The optimal depth of internal dump location, taking into account the parameters of the quarry field, the design and expedient depth of mining the deposit, is:

- for deposits with a large area: with low and medium thickness of overburden rocks - the maximum depth does not depend on the depth of the internal dump location; with a large thickness of overburden rocks $-70-115 \mathrm{~m}$;

- for deposits with a medium area: $-50-90 \mathrm{~m}$;

- for deposits with a small area: $-50-85 \mathrm{~m}$.

From the above, based on the research results, it can be stated that the design depth of the quarry (the maximum of estimated reserves) is rational to take as the depth of internal dumping.

The patterns of a change in the maximum depth of mining the basic deposits depending on the main parameters of the quarry field are studied with application of statistical processing according to systematized types of deposits on the basis of the developed methodology. The main parameters of deposits are processed using modern computer technologies with the methods of mathematical statistics. Using the leastsquares method, correlation dependences have been determined of the maximum mining depth $\left(H^{q}\right.$ max $)$ on the length $\left(L_{q}\right)$, width $\left(B_{q}\right)$, overburden rocks thickness $\left(h_{\text {over }}\right)$ and the depth of internal dumping $\left(H_{\text {fill }}\right)$ for typical deposits according to mining schemes C and D [29], [47], [48]:

1) for deposits with a large area:

- with a low thickness of overburden rocks:

$$
H_{\max }^{q}=17.04-0.98 h_{\text {over }}+0.02 L_{q}+0.43 B_{q}-0.12 H_{\text {fill }}
$$

- with a medium thickness of overburden rocks:

$$
H_{\max }^{q}=13.85-1.88 h_{\text {over }}+0.01 L_{q}+0.46 B_{q}+0.33 H_{\text {fill }} ;
$$

- with a large thickness of overburden rocks:

$$
\text { -for the scheme } C \text { : }
$$$$
H_{\max }^{q}=250.07+0.72 h_{\text {over }}+0.19 L_{q}+0.45 B_{q}-0.38 H_{\text {fill }}
$$

- for the scheme D:

$$
H_{\max }^{q}=-4865.48+100.07 h_{\text {over }}-2.33 L_{q}+7.74 B_{q}-16.33 H_{\text {fill }} \text {; }
$$

2) for deposits with a medium area:

- with a low thickness of overburden rocks:

- along the length of the quarry field:

$$
H_{\max }^{q}=10.2-5.46 h_{\text {over }}+0.41 L_{q}+0.01 B_{q}+0.32 H_{\text {fill }} \text {; }
$$

- across the width of the quarry field: 
$H_{\max }^{q}=7.97+0.01 h_{\text {over }}-0.01 L_{q}+0.49 B_{q}+0.12 H_{\text {fill }}$

- with a medium thickness of overburden rocks:

- along the length of the quarry field:

$H_{\max }^{q}=31.96-5.35 h_{\text {over }}+0.35 L_{q}-0.02 B_{q}+0.72 H_{\text {fill }}$

- across the width of the quarry field:

$H_{\max }^{q}=71.82-0.71 h_{\text {over }}-0.01 L_{q}+0.39 B_{q}-0.11 H_{\text {fill }}$

- with a large thickness of overburden rocks:

- along the length of the quarry field:

- for the scheme $C$ :

$H_{\max }^{q}=48.4-2.78 h_{\text {over }}+0.3 L_{q}+0.12 B_{q}-0.51 H_{\text {fill }} ;$

- for the scheme D:

$H_{\max }^{q}=-164.56+8.19 h_{\text {over }}+0.53 L_{q}-0.38 B_{q}+0.63 H_{\text {fill }} ;$

- across the width of the quarry field:

$H_{\max }^{q}=543.74-3.0 h_{\text {over }}-1.07 L_{q}+1.41 B_{q}+11.67 H_{\text {fill }}$;

3) for deposits with a small area:

- with a low thickness of overburden rocks:

- along the length of the quarry field:

$H_{\max }^{q}=23.37-4.74 h_{\text {over }}+0.37 L_{q}+0.07 B_{q}-0.005 H_{\text {fill }}$;

- across the width of the quarry field:

$H_{\max }^{q}=-4.01+0.59 h_{\text {over }}+0.003 L_{q}+0.5 B_{q}+0.02 H_{\text {fill }} ;$

- with a medium thickness of overburden rocks:

- along the length of the quarry field:

$H_{\max }^{q}=53.45-4.86 h_{\text {over }}+0.34 L_{q}-0.03 B_{q}+0.25 H_{\text {fill }}$;

- across the width of the quarry field:

$H_{\max }^{q}=-22.26+0.09 h_{\text {over }}-0.01 L_{q}+0.54 B_{q}+0.28 H_{\text {fill }}$

- with a large thickness of overburden rocks:

- for the scheme $C$ :

$H_{\max }^{q}=-1.14-3.54 h_{\text {over }}+0.58 L_{q}-0.27 B_{q}-0.003 H_{\text {fill }}$;

- for the scheme D:

$H_{\max }^{q}=31.14+0.7 h_{\text {over }}+0.08 L_{q}+0.53 B_{q}-0.49 H_{\text {fill }}$.

Analyzing the obtained results, the dependences of the maximum mining depth $\left(H^{q} \max \right)$ on the main parameters of the quarry field (length, width and thickness of overburden rocks) and the depth of internal dumping $\left(H_{\text {fill }}\right)$, it can be concluded that the maximum mining depth of typical deposits will be:

1) for deposits with a large area:

- with a low thickness of overburden rocks: $388 \mathrm{~m}$;

- with a medium thickness of overburden rocks: $355 \mathrm{~m}$;

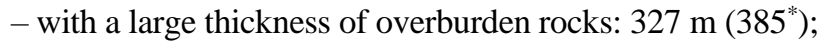

2) for deposits with a medium area:

- with a low thickness of overburden rocks: $238 \mathrm{~m}$;

- with a medium thickness of overburden rocks: 209 m;
- with a large thickness of overburden rocks: $217 \mathrm{~m}\left(258^{*}\right)$;

3) for deposits with a small area:

- with a low thickness of overburden rocks: $158 \mathrm{~m}$;

- with a medium thickness of overburden rocks: $155 \mathrm{~m}$;

- with a large thickness of overburden rocks: $134 \mathrm{~m}\left(169^{*}\right)$;

* maximum mining depth according to the scheme D.

After mining out of the approved reserves of the Liubymivske granite deposit and formation of the internal dump, a significant area remains of the quarry bottom, which is $78930 \mathrm{~m}^{2}$. As a result of additional exploration and putting of the specified volumes of reserves on the balance sheet, their further extraction is possible (Fig. 3).

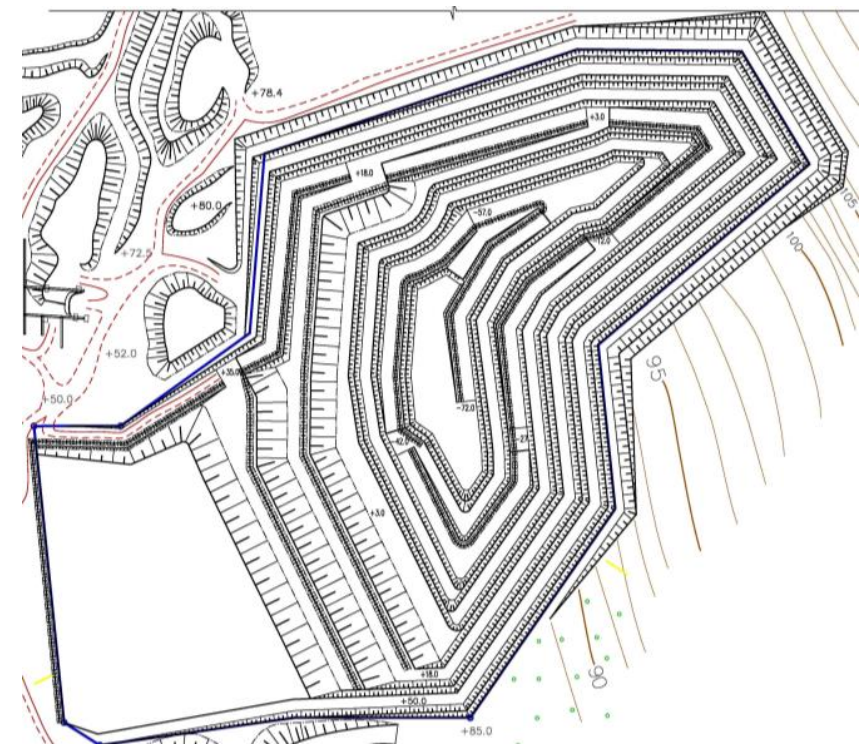

Figure 3. Setting the maximum depth of mining by the graphic method

Given that the minimum acceptable profitability of the enterprise should be not less than the bank rate on the deposit [49], the minimum acceptable "total cost" of the finished product will be $-290-340 \mathrm{UAH} / \mathrm{m}^{3}$. Taking into account these indicators, the dependences of a change in the economically expedient depth of mining the typical deposits have been obtained (Fig. 4).

Based on the obtained dependences, the economically expedient depth of mining the typical deposits has been substantiated (Tables 1 and 2).

In order to implement the presented research results in non-metallic granite quarries, recommendations of the main provisions have been developed. The generalized essence of these recommendations is given using the example of the Liubymivske granite deposit, which is a rather typical representative of non-metallic deposits of Prydniprovia.

Analyzing the results obtained to substantiate the depth of mining the Liubymivske deposit using graphoanalytical and analytical methods, it can be concluded that the determining parameter in achieving the maximum depth of mining in this case is the width of the quarry field, resulting in the maximum depth of 160-172 m. Having studied the obtained results, it can be seen the error in different methods of solving the problem, namely: the developed methodology, the obtained correlation dependences and the graphical method is $2-7 \%$. This error is insignificant given the spatial complexity of the quarry field shape. 

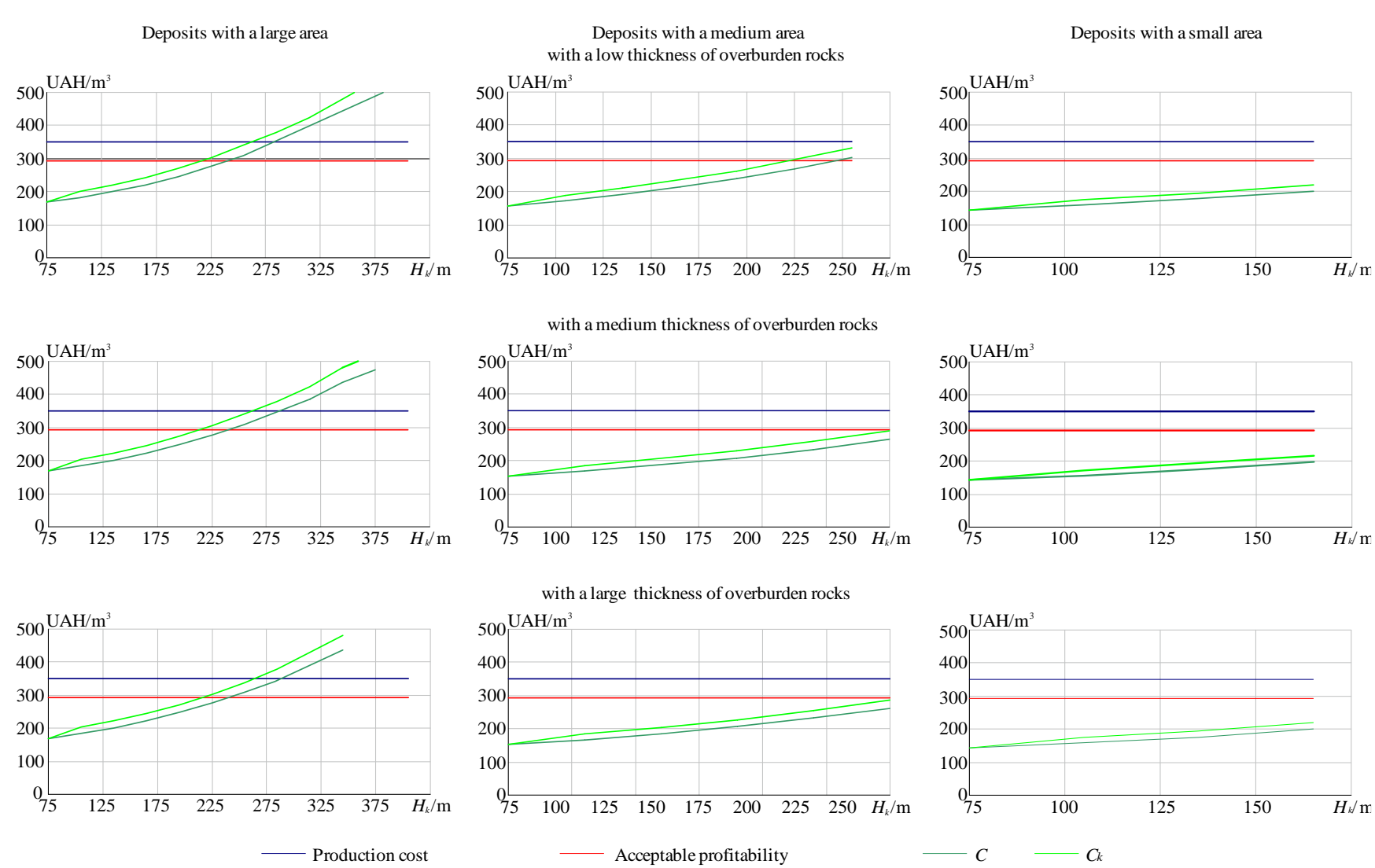

Figure 3. Substantiation of economically expedient depth of mining the typical deposits: $C$ - total cost of production, $C_{k}-$ total cost of production considering the coefficients that take into account the complexity of the production process conditions with increasing depth of the quarry and the time factor

Table 1. Economically expedient depth of mining according to the scheme C

\begin{tabular}{|c|c|c|c|c|}
\hline \multirow[b]{2}{*}{$\begin{array}{l}\text { A group of fields by } \\
\text { spatial dimensions }\end{array}$} & \multirow{2}{*}{$\begin{array}{c}\text { Type of fields by thickness } \\
\text { of overburden rocks }\end{array}$} & \multicolumn{2}{|c|}{ Quarry depth, m } & \multirow{2}{*}{$\begin{array}{l}\text { Cost, } C, \\
\mathrm{UAH} / \mathrm{m}^{3}\end{array}$} \\
\hline & & Maximum & $\begin{array}{l}\text { Economically } \\
\text { expedient }\end{array}$ & \\
\hline \multirow{3}{*}{ With a large area } & With a low thickness & 388 & $220-240$ & $290-300$ \\
\hline & With a medium thickness & 355 & $220-240$ & $290-300$ \\
\hline & With a large thickness & 327 & $220-240$ & $290-300$ \\
\hline \multirow{3}{*}{ With a medium area } & With a low thickness & 238 & $225-238$ & $280-290$ \\
\hline & With a medium thickness & 209 & 209 & $260-275$ \\
\hline & With a large thickness & 217 & 217 & $265-280$ \\
\hline \multirow{3}{*}{ With a small area } & With a low thickness & 158 & 158 & $190-220$ \\
\hline & With a medium thickness & 155 & 155 & $185-215$ \\
\hline & With a large thickness & 134 & 134 & $170-190$ \\
\hline
\end{tabular}

Table 2. Economically expedient depth of mining according to the scheme D

\begin{tabular}{|c|c|c|c|c|}
\hline \multirow{2}{*}{$\begin{array}{l}\text { A group of fields by } \\
\text { spatial dimensions }\end{array}$} & \multirow{2}{*}{$\begin{array}{c}\text { Type of fields by thickness } \\
\text { of overburden rocks }\end{array}$} & \multicolumn{2}{|c|}{ Quarry depth, m } & \multirow{2}{*}{$\begin{array}{l}\text { Cost, } C, \\
\mathrm{UAH} / \mathrm{m}^{3}\end{array}$} \\
\hline & & Maximum & $\begin{array}{l}\text { Economically } \\
\text { expedient }\end{array}$ & \\
\hline With a large area & \multirow{3}{*}{ With a large thickness } & 385 & 200 & 290 \\
\hline With a medium area & & 258 & 230 & 290 \\
\hline With a small area & & 169 & 169 & 265 \\
\hline
\end{tabular}

\section{Conclusions}

As a result of the research performed, it has been determined that the optimal depth of internal dumping, which provides the maximum depth of mining the deposit, is: for the deposits with a large area and with a large thickness of overburden rocks $H_{\text {fill }}=70-115 \mathrm{~m}$; for the deposits with a medium area $-H_{\text {fill }}=50-90 \mathrm{~m}$; for the deposits with a small area $H_{\text {fill }}=50-85 \mathrm{~m}$. In quarries of large area with small and medium thickness of overburden rocks, $H^{q}$ max does not depend on the depth of internal dumping. The design depth of the quarry is expedient to take as the depth of internal dumping.
Based on the obtained new dependences between the maximum mining depth and the main parameters of the quarry fields (length and width, thickness of overburden rocks and depth of internal dumping), the value of $H^{q}$ max has been determined for typical deposits of small, medium and large thickness of overburden rocks, respectively: large area -388 , 355, 327 (385) m; medium area - 238, 209, 217 (258) m; small area $-158,155,134(169) \mathrm{m}$. At the same time, the value given in parentheses corresponds to the conditions of internal dumping with its repeated transfer to the mined-out space after additional mining of reserves. 
It has been determined that the growth of the total cost of the finished products with the depth of mining operations is largely influenced by the cost of drainage and transportation of minerals to the Crushing and screening plant. The amount of water-removing costs for typical deposists increases from 1.9 to $12.45 \mathrm{UAH} / \mathrm{m}^{3}$, and transportation costs from 26 to $323 \mathrm{UAH} / \mathrm{m}^{3}$.

Given that the profitability of the enterprise should be not less than the bank rate on the deposit (16\%), it has been determined the minimum acceptable total cost of the finished product in the range of $290-340 \mathrm{UAH} / \mathrm{m}^{3}$. Based on this, the developed methodology substantiates the economically expedient depth of mining the typical deposits, which is: for the deposits with a large area - 220-240 m; for the deposits with a medium area with low, medium and large thickness of overburden rocks - 225-238 m, 209 m, 217 (230) m, respectively; for the deposits with a small area with low, medium and large thickness of overburden rocks $-158 \mathrm{~m}, 155 \mathrm{~m}$ and 134 (169) m, respectively. At the same time, the depth value given in parentheses corresponds to the conditions of internal dumping with its repeated transfer to the mined-out space.

The substantiated depth of mining the non-metallic deposits of rocky minerals with stockpiling of overburden rocks in the mined-out space will allow as a result of additional exploration of mineral reserves their additional increment in the volume from 1 to 48 million $\mathrm{m}^{3}$, which will ensure 5-40 years of sustainable operation of the mining enterprise.

The research results have been tested under the conditions of mining the Liubymivske granite deposit, which, according to the classification peculiarities, belongs to the deposits with a medium area and with a medium thickness of overburden rocks. It has been found that the maximum depth of the quarry will be $160-172 \mathrm{~m}$.

The error of the obtained results by different methods does not exceed $7 \%$ relative to the data of the obtained correlation dependences. At the same time, the field development to the specified economically expedient depth will provide an increment of the additional mineral reserves in the volume of 2.8 million $\mathrm{m}^{3}$, and increase the operational life of the quarry by more than 18 years.

\section{Acknowledgements}

This research is performed within the framework of the working projects development for operating enterprises of Ukraine, developed on economic contract topics, completed by the Institute for the Design of Mining Enterprises of the Dnipro Polytechnic National Technical University: \#110054 "Addendum to the working project of mining the Liubymivske granite deposit: mining out of incremental reserves", \#110011 “Adjustment of the working project of mining the Sofiivske deposit: The project for reconstruction of mining the Sofiievka crushed-stone quarry" and \#71302/1 "Addendum to the working project of mining the Mykytivka granite deposit: Mining out of incremental reserves", as well as within the framework of performing the research work on state budget topics of the Ministry of Education and Science of Ukraine "Substantiation of the latest technological solutions for mining the mineral deposits in the context of sustainable development of mining regions" (Number of State Registration \#0120U102078).

\section{References}

[1] Perederij, V. (2001). Clay mineral composition and palaeoclimatic interpretation of the Pleistocene deposits of Ukraine. Quaternary International, (76-77), 113-121. https://doi.org/10.1016/s1040-6182(00)00095-1

[2] Klimchouk, A.B. (1997). The role of karst in the genesis of sulfur deposits, Pre-Carpathian region, Ukraine. Environmental Geology, 31(1-2), 1-20. https://doi.org/10.1007/s002540050158

[3] Dryzhenko, A., Moldabayev, S., Shustov, A., Adamchuk, A., \& Sarybayev, N. (2017). Open pit mining technology of steeply dipping mineral occurences by steeply inclined sublayers. International Multidisciplinary Scientific GeoConference Surveying Geology and Mining Ecology Management, 17(13), 599-606. https://doi.org/10.5593/sgem2017/13/s03.076

[4] Medvedieva, O., Lapshyn, Y., Koval, N., Zeynullin, A., \& Gupalo, O. (2020). The resource-saving technology to restore the accumulation ability of tailing ponds. E3S Web of Conferences, (168), 00054. https://doi.org/10.1051/e3sconf/202016800054

[5] Menshov, O., Spassov, S., Camps, P., Vyzhva, S., Pereira, P., Pastushenko, T., \& Demidov, V. (2020). Soil and dust magnetism in semiurban area Truskavets, Ukraine. Environmental Earth Sciences, (79), 1-10. https://doi.org/10.1007/s12665-020-08924-5

[6] Menshov, O., Kruglov, O., Vyzhva, S., Horoshkova, L., Pereira, P., Pastushenko, T., \& Dindaroglu, T. (2021). Landscape position effects on magnetic properties of soils in the agricultural land Pechenigy, Ukraine. Earth Systems and Environment, 1-12. https://doi.org/10.1007/s41748021-00240-7

[7] Pivnyak, G.G., Gumenik, I.L., Drebenshtedt, C., \& Panasenko, A.I. (2011). Nauchnyie osnovy ratsyonalnogo prirodopolzovaniya pri otkrytoy razrabotke mestorozhdeniy. Dnepropetrovsk, Ukraina: NMU.

[8] Stupnik, M., Kolosov, V., Pysmennyi, S., \& Kostiantyn, K. (2019). Selective mining of complex stuctured ore deposits by open stope systems. E3S Web of Conferences, (123), 01007. https://doi.org/10.1051/e3sconf/201912301007

[9] Naduty, V., Malanchuk, Z., Malanchuk, Y., \& Korniyenko, V. (2016) Research results proving the dependence of the copper concentrate amount recovered from basalt raw material on the electric separator field intensity. Eastern-European Journal of Enterprise Technologies, 5(5(83)), 19-24. https://doi.org/10.15587/1729-4061.2016.79524

[10] Khomenko, O.Ye. (2012). Implementation of energy method in study of zonal disintegration of rocks. Naukovyi Visnyk Natsionalnoho Hirnychoho Universytetu, (4), 44-54.

[11] Pivniak, H.H., Pilov, P.I., Pashkevych, M.S., \& Shashenko, D.O. (2012). Synchro-mining: Civilized solution of problems of mining regions' sustainable operation. Naukovyi Visnyk Natsionalnoho Hirnychoho Universytetu, (3), 131-138.

[12] Malanchuk, Z., Zaiets, V., Tyhonchuk, L., Moshchych, S., Gayabazar, G., \& Dang, P.T. (2021). Research of the properties of quarry tuffstone for complex processing. E3S Web of Conferences, (280), 01003. https://doi.org/10.1051/e3sconf/202128001003

[13] Bitimbaev, M.Z., Krupnik, L.A., Aben, E.K., \& Aben, K.K. (2017). Adjustment of backfill composition for mineral mining under open pit bottom. Gornyi Zhurnal, (2), 57-61. https://doi.org/10.17580/gzh.2017.02.10

[14] Kyrgizbayeva, G., Nurpeisov, M., \& Sarybayev, O. (2015). The monitoring of earth surface displacements during the subsoil development. New Developments in Mining Engineering 2015: Theoretical and Practical Solutions of Mineral Resources Mining, 161-167. https://doi.org/10.1201/b19901-30

[15] Kalybekov, T., Rysbekov, K., \& Zhakypbek, Y. (2015). Efficient land use in open-cut mining. New Developments in Mining Engineering 2015: Theoretical and Practical Solutions of Mineral Resources Mining, 287-291. https://doi.org/10.1201/b19901-51

[16] Baibatsha, A., Dyussembayeva, K., \& Bekbotayeva, A. (2016). Study of tails enrichment factory Zhezkazgan as a technogenic ore deposits. International Multidisciplinary Scientific GeoConference Surveying Geology and Mining Ecology Management, (1), 579-586. https://doi.org/10.5593/sgem2016/b11/s01.073

[17] Pavlychenko, A., \& Kovalenko, A. (2013). The investigation of rock dumps influence to the levels of heavy metals contamination of soil. Annual Scientific-Technical Collection - Mining of Mineral Deposits, 237-238. https://doi.org/10.1201/b16354-43

[18] Gorova, A., Pavlychenko, A., \& Borysovs'ka, O. (2013). The study of ecological state of waste disposal areas of energy and mining companies. Annual Scientific-Technical Collection - Mining of Mineral Deposits, 169-172. https://doi.org/10.1201/b16354-29

[19] Malanchuk, Z., Malanchuk, Y., Korniyenko, V., \& Ignatyuk, I. (2017). Examining features of the process of heavy metals distribution in technogenic placers at hydraulic mining. Eastern-European Journal of Enterprise Technologies, 1(10(85)), 45-51. https://doi.org/10.15587/1729$\underline{4061.2017 .92638}$ 
[20] Taran, I.A. (2012). Laws of power transmission on branches of doublesplit hydrostatic mechanical transmissions. Naukovyi Visnyk Natsionalnoho Hirnychoho Universytetu, (2), 69-75.

[21] Bondarenko, V.I., Samusya, V.I., Smolanov, S.N. (2005). Mobile lifting units for wrecking works in pit shafts. Gornyi Zhurnal, (5), 99-100.

[22] Taran, I.A. (2012). Interrelation of circular transfer ratio of double-split transmissions with regulation characteristic in case of planetary gear output. Naukovyi Visnyk Natsionalnoho Hirnychoho Universytetu, (3), 78-85.

[23] Simonenko, V.I. (2004). Razrabotka energosberegayushchey tekhnologii dobychi skal'nykh nerudnykh poleznykh iskopaemykh Ukrainy. Dissertatsiya doktora tekhnicheskikh nauk. Dnepropetrovsk, Ukraina: NGU.

[24] Anisimov, O., Symonenko, V., Cherniaiev, O., \& Shustov, O. (2018) Formation of safety conditions for development of deposits by open mining. E3S Web of Conferences, (60), 00016 https://doi.org/10.1051/e3sconf/20186000016

[25] Lyashenko, V.I., Dyatchin, V.Z., \& Lisovoy, I.A. (2018). Increase of environmental safety of mining production on the basis of waste utilization of extraction and processing of ore raw materials. Ecology and Industry of Russia, 22(4), 4-10. https://doi.org/10.18412/1816-03952018-4-4-10

[26] Baibatsha, A., Dussembayeva, K., Bekbotayeva, A., \& Abdullayeva, M.T. (2018). Tails of enrichment factories as the technogenic mineral resources. International Multidisciplinary Scientific GeoConference Surveying Geology and Mining Ecology Management, 18(1), 519-526. https://doi.org/10.5593/sgem2018/1.1/s01.066

[27] Lyashenko, V. (2018). Safety improving of mine preparation works at the ore mines. Bezopasnost' Truda v Promyshlennosti, (5), 53-59. https://doi:10.24000/0409-2961-2018-5-53-59

[28] Strilets, O., Pcholkin, G., \& Oliferuk, V. (2015). Monitoring of mass blasting seismic impact on residencial buildings and constructions. New Developments in Mining Engineering 2015: Theoretical and Practical Solutions of Mineral Resources Mining, 533-535. https://doi.org/10.1201/b19901-91

[29] Simonenko, V.I. (2016). Rozrobka ekolohobezpechnykh tekhnolohii vedennia hirnychykh robit $z$ urakhuvanniam potreb $v$ likvidatsii ta konservatsii hirnychodobuvnykh pidpryiemstv. Zvit \#DR 0115U002301. Dnipropetrovsk, Ukraina: Natsionalnyi hirnychyi universytet.

[30] Cherniaiev, O.V. (2017). Systematization of the hard rock non-metallic mineral deposits for improvement of their mining technologies. Naukovyi Visnyk Natsionalnoho Hirnychoho Universytetu, (5), 11-17.

[31] Gorova, A., Pavlychenko, A., Kulyna, S., \& Shkremetko, O. (2012). Ecological problems of post-industrial mining areas. Geomechanical Processes During Underground Mining, 35-40. https://doi.org/10.1201/b13157-7

[32] Dychkovskyi, R., Vladyko, O., Maltsev, D., \& Cabana, E.C. (2018). Some aspects of the compatibility of mineral mining technologies. Rudarsko-Geološko-Naftni Zbornik, 33(4), 73-82. https://doi.org/10.17794/rgn.2018.4.7

[33] Falshtynskyi, V.S., Dychkovskyi, R.O., Lozynskyi, V.G., \& Saik, P.B. (2013). Determination of the technological parameters of borehole underground coal gasification for thin coal seams. Journal of Sustainable Mining, 12(3), 8-16. https://doi.org/10.7424/jsm130302

[34] Kieush, L., Boyko, M., Koveria, A., Yaholnyk, M., \& Poliakova, N. (2020). Manganese sinter production with wood biomass application. Key Engineering Materials, (844), 124-134. https://doi.org/10.4028/www.scientific.net/kem.844.124

[35] Saik, P., Petlovanyi, M., Lozynskyi, V., Sai, K., \& Merzlikin, A (2018). Innovative approach to the integrated use of energy resources of

\section{Обгрунтування ресурсозберігаючої технології розробки родовищ 3 виробництва щебеневої продукції}

\section{О. Черняєв, А. Павличенко, О. Романенко, Ю. Вовк}

Мета. Наукове обгрунтування доцільної глибини розробки нерудних родовищ скельних корисних копалин на основі математичних і статистичних методів, що забезпечить ресурсозбереження та раціональне використання природних ресурсів

Методика. Для вирішення поставленої мети використані наступні методи: графо-аналітичний - при оптимізації максимальної глибини розробки родовищ будівельних матеріалів, а також метод математичного моделювання - для визначення максимальної глибини розробки нерудних родовищ із внутрішнім відвалоутворенням. Дослідження закономірностей зміни максимальної глибини розробки базових родовищ від головних параметрів кар'єрного поля виконано шляхом статистичної обробки за систематизованими типами родовищ.

Результати. Розроблена нова методика розрахунку граничної глибини гранітних кар'єрів, що відрізняється врахуванням внутрішньокар'єрного відвалоутворення, яке найбільше впливає на ефективність ведення гірничих робіт і величину економічних показників при забезпеченні максимального економічного ефекту з досягненням раціональної граничної глибини відпрацювання покладу. Створено нову, теоретично обгрунтовану, методику визначення граничної глибини розробки родовищ мінеральної сировини для виробництва щебеневої продукції із забезпеченням ресурсо- та землезбереження в процесі експлуатації карєрів.

Наукова новизна. Вперше для зазначених родовищ встановлена залежність їхньої граничної глибини відпрацювання від головних параметрів кар'єрного поля та місця формування внутрішнього відвала розкривних порід, що стало визначальним фактором 
доцільної розробки глибоких нерудних родовищ будівельних матеріалів із внутрішнім відвалоутворенням при мінімальному порушенні земель.

Практична значимість. Результати досліджень апробовані та впроваджені у робочих проектах розробки Любимівського, Чаплинського, Первомайського, Микитівського, Трикратського та Новоукраїнського родовищ гранітів; в результаті дорозвідки запасів корисної копалини можливе їх додаткове прирощення у обсязі від 1 до 48 млн м³ ня гірничодобувного підприємства.

Ключові слова: неметалеві кар'єри, технологічна схема розробки, глибина формування відвалу, внутрішній відвал, максимальна глибина розробки

\section{Обоснование ресурсосберегающей технологии разработки месторождений по производству щебеночной продукции}

\section{А. Черняев, А. Павличенко, А. Романенко, Ю. Вовк}

Цель. Научное обоснование целесообразной глубины разработки нерудных месторождений скальных полезных ископаемых на основе математических и статистических методов, что обеспечит ресурсосбережение и рациональное использование природных ресурсов.

Методика. Для решения поставленной цели использованы следующие методы: графо-аналитический - при оптимизации максимальной глубины разработки месторождений строительных материалов, а также метод математического моделирования - для определения максимальной глубины разработки нерудных месторождений с внутренним отвалообразованием. Исследование закономерностей изменения максимальной глубины разработки базовых месторождений от основных параметров карьерного поля выполнено путем статистической обработки по систематизированным типам месторождений.

Результаты. Разработана новая методика расчета предельной глубины гранитных карьеров, отличающаяся учетом внутрикарьерного отвалообразования, которое больше всего влияет на эффективность ведения горных работ и величину экономических показателей при обеспечении максимального экономического эффекта с достижением рациональной предельной глубины отработки месторождения. Создана новая, теоретически обоснованная, методика определения предельной глубины разработки месторождений минерального сырья для производства щебеночной продукции с обеспечением ресурсо- и землесбережения в процессе эксплуатации карьеров.

Научная новизна. Впервые для указанных месторождений установлена зависимость их предельной глубины отработки от главных параметров карьерного поля и места формирования внутреннего отвала вскрышных пород, что стало определяющим фактором целесообразной разработки глубоких нерудных месторождений строительных материалов с внутренним отвалообразованием при минимальном нарушении земель.

Практическая значимость. Результаты исследований апробированы и внедрены в рабочих проектах разработки Любимовского, Чаплинского, Первомайского, Никитовского, Трикратского и Новоукраинского месторождений гранитов; в результате доразведки запасов полезного ископаемого возможно их дополнительное приращение в объеме от 1 до 48 млн м³, что обеспечит 5-40 лет устойчивого функционирования горнодобывающего предприятия.

Ключевые слова: неметаллические карьеры, технологическая схема разработки, глубина формирования отвала, внутренний отвал, максимальная глубина разработки 